\section{Oral Mucosa Lichen Planus: Case Presentation}

\section{Leroy Olaechea Varona ${ }^{1}$, Maria Teresa Diaz $^{2}$ and Freddy Alvarez Diaz $^{3}$}

${ }^{1}$ Specialist in General Medicine, Department of Dermatology, Rob Ferreira Hospital, Nelspruit Mpumalanga, South Africa

${ }^{2}$ Specialist in 2nd degree Dermatology and Infectology, Rob Ferreira Hospital, Nelspruit Mpumalanga, South Africa

${ }^{3}$ Specialist in family Medicine, Rob Ferreira Hospital, Nelspruit Mpumalanga, South Africa

\begin{abstract}
Objective: Lichen planus is a chronic inflammatory and immune disease that affects the skin, nails, hair, and mucous membranes. It is characterized by polygonal, flat-topped, violaceous papules and plaques with overlying, reticulated, fine white scale (Wickham's striae), commonly affecting dorsal hands, flexural wrists and forearms, trunk, anterior lower legs and mucosa membranes.
\end{abstract}

Aim: The aim of this prospective observational study was to describe the features of this patient in our tertiary hospital.

Methods: This case wasseen by stomatology department of our hospital with mouth and oral mucosa lesions over the period of six months. Co-morbidity diagnoses, clinical features, investigations and complications were noted.

Results: Female patient with histologic and clinical diagnosis of lichen planus. No skin lesions were seen during the examination and during the follow up clinics. She is progressing very well and at the moment improved a $90 \%$, almost healed.

Conclusion: Lesions were consisted of oral mucosa lichen planus, confirmed by histology report. Patient is doing well with the treatment of steroids mouth washes.

Keywords: Lichen planus; Liquenoid lesions; Oral mucosa; Skin

"Corresponding author: Leroy Olaechea Varona, Department of Dermatology, Rob Ferreira Hospital, Nelspruit Mpumalanga, South Africa, Tel: +27 790429469 E-mail: leroylsster@gmail.com

Citation: Varona LO, Diaz MT, Diaz FA (2019) Oral Mucosa Lichen Planus: Case Presentation. J Surg Curr Trend Innov 3: 024.

Received: December 04, 2019; Accepted: December 19, 2019; Published: December 27, 2019

Copyright: () 2019 Varona LO, et al. This is an open-access article distributed under the terms of the Creative Commons Attribution License, which permits un restricted use, distribution, and reproduction in any medium, provided the original author and source are credited.

\section{Introduction}

Lichen planus was first reported in 1869 by Erasmus Wilson. The origin of the word is believed to be from the Greek word "Leichen", which means tree moss; and also from Latin word "planus" which means flat and even surface. Dr Wilson explained the condition as an inflammatory disorder with unknown etiology. Initially, the characteristic surface markings or striae was described by Weyl in 1885 . In 1895, Wickham further explained the characteristic of the lesion, now known as Wickham striae. Further on, Darier explained the presence of such characteristic markings by correlating with an increase thickness of the granular cell layer. The coexistence of oral, cervical and stomach lichen planus lesions were described by Guogerot and Burnier in 1937 [1].

A similar variant of mucosal lichen planus as the vulvovaginal-gingival syndrome with erosive lesions involving oral and vulvovaginal mucosa were introduced by Pelisse and colleagues in year 1982.

Lichen planus is a skin rash triggered by the immune system. It's not known why the immune response occurs. So there is no cure. There may be several contributing factors, and each case is different. Potential causes include: viral infections, allergens, stress, and genetics [2].

Sometimes lichen planus occurs along with autoimmune disorders. While it may be uncomfortable, in most cases lichen planus is not a serious condition. It's not contagious. However, there are some rare variations of the condition that may be serious and painful [3].

We are presenting a case of a female patient, 29 years old, no other illnesses, and no family history of skin diseases, nor chronic illnesses. Personal history she started a new position at the bank. Who was seeing by her dentist for a follow up consultation, she had a root canal treatment 7 month ago, and now saw the lesion and treated with antiseptic mouth washes and honey. Lesions persisted and extended to lips. That's why she was referred to our clinic. Complaining of pain and sometimes itching. After tooth brushing blood can be seen sometimes.

\section{On examination}

- No skin lesions were found

- Viginal mucosa was intact, no lesions no discharge

- Oral mucosa: a wild spread white striations, linear type, with exulcerations and extended areas of redness and white patches. Localized on inner cheeks, tongue and lips

\section{Investigations:}

- We took sample for culture and biopsy

- Culture was negative, normal flora, no fungal infection or bacteria.

- Biopsy result came in a week with this description

- Parakeratosis and slight acanthosis of the epithelium. A lichenoid (band-like) mixed lymphohistiocytic infiltrate in the submucosa

- Consisted of Lichen planus 
It generally occurs more commonly in females, in a ratio of $3: 2$, and most cases are diagnosed between the ages of 30 and 60 , but it can occur at any age. Lichen planus can occur in patients as diverse cutaneous manifestations alone or in combination with mucosal lichen planus and, or lichen planus of the nails. Study shows that frequency of mucosal involvement of lichen planus patients is $30-70 \%$. Oral lichen planus is relatively common; it is one of the most common mucosal diseases [4-6].

A diagnosis of oral Lichen Planus (LP) is confirmed through review of the patient history, physical examination, and histologic findings. The clinical evaluation should include a patient history that assesses the following: History of LP involving other body sites or other skin disorders that may present with similar findings (eg, autoimmune blistering diseases)

\section{Presence of associated symptoms (eg, pain, burning)}

Medication the patients are taking within the few weeks to months after drug initiation eg. Antihypertensives, antidepressants, diuretics, ant diabetics, NSAIDS and etc. to evaluate for the possibility of an oral lichenoid drug eruption

History of dental restorations, use of dental appliances, or oral exposure to substances that may cause oral lichenoid contact eruptions (eg. dental composites, cobalt chromium based dentures etc) [7].

\section{Other diagnosis must be ruled out}

Lichenoid drug eruption: The cutaneous manifestations resemble idiopathic lichen planus. Chronic graft-versus-host disease: The history of preceding hematopoietic cell transplant is helpful for diagnosis. Psoriasis. Atopic dermatitis. Cutaneous lupus erythematous. Discoid lupus erythematous (Figures 1 and 2).

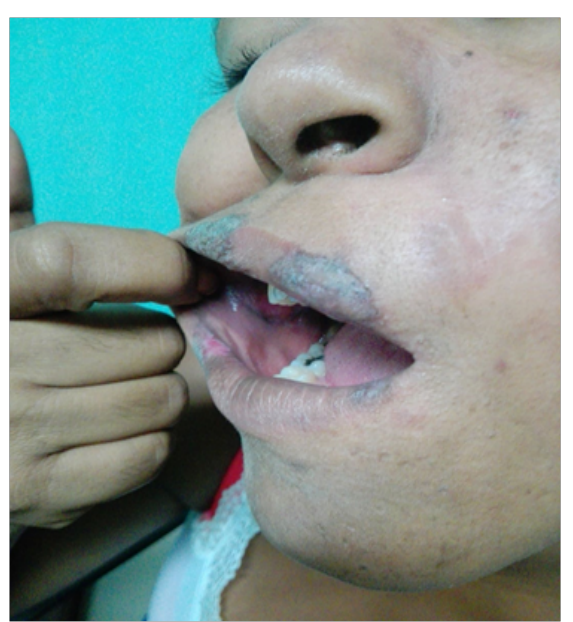

Figure 1: Taken at the clinic: Erythematous violaceum plaques can be seen on lips, and mucosa.

There is no cure for lichen planus, and so treatment of cutaneous and oral lichen planus is for symptomatic relief or due to cosmetic concerns. When medical treatment is pursued, first-line treatment typically involves corticosteroids, and removal of any triggers. Without treatment, most lesions will spontaneously resolve within 6-9 months for cutaneous lesions, and longer for mucosal lesions [8-15] (Figure $3)$.
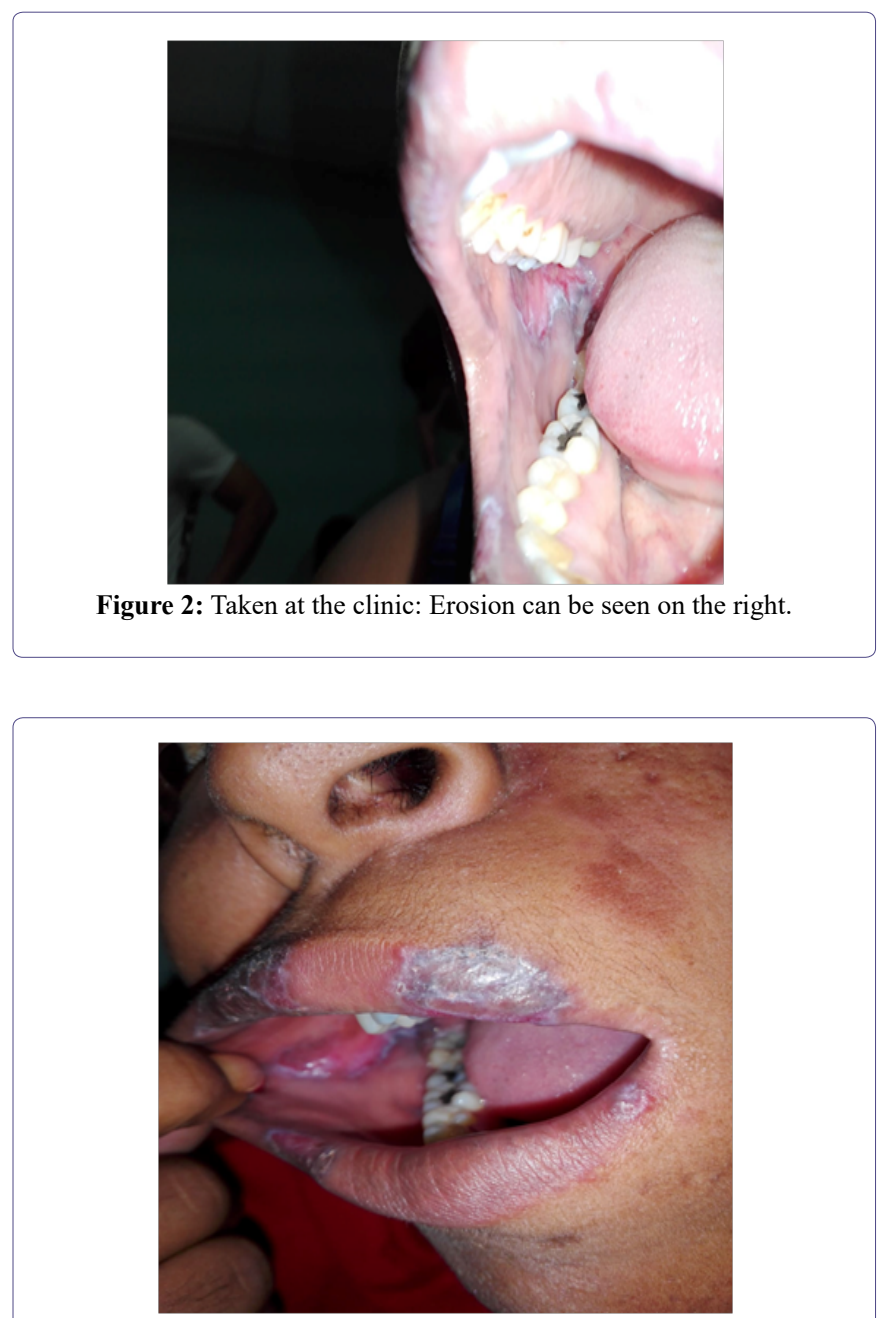

Figure 3: Taken at the clinic after 3 weeks with treatment, Lesions on lips and mucosa healing.

The condition is benign, elimination of precipitating factors and improving oral hygiene are considered initial management for symptomatic OLP, and these measures are reported to be useful. Treatment usually involves topical corticosteroids (such as betamethasone, clobetasol, dexamethasone, and triamcinolone) and analgesics, or if these are ineffective and the condition is severe, then systemic corticosteroids may be used. Calcineurin inhibitors (such as pimecrolimus, tacrolimus or cyclosporin) are sometimes used [15-28].

\section{Conclusion}

In this case clinical features were consisted of OLP. Diagnosis was confirmed by biopsy [29-41]. Possible cause was the root canal treatment she had 7 month ago, before the lesions appeared, also she is been under stress due to her new employment as a General Manager in a bank. She is responding very well to the medication. She improved $90 \%$ in the last clinic.

\section{Acknowledgement}

All authors contributed equally with study design, data collection and analysis interpretation. Manuscript was written by Dr. LO Varona and revised by Dr. Diaz Renon. 


\section{Conflict of Interest}

None declared.

\section{References}

1. AOCD (2019) Lichen planus, American Osteopathic College of Dermatology, Kirksville, USA.

2. ASA ((2012) Lichen planus, American Skin Association, New York, USA.

3. MC (2018) Lichen planus, Mayo Clinic Staff, Minnesota, USA.

4. Mary Ellen Ellis (2018) Lichen Planus. In: Alana Biggers (ed.). New York, USA.

5. Gorouhi F, Davari P, Fazel N (2014) Cutaneous and mucosal lichen planus A comprehensive review of clinical subtypes, risk factors, diagnosis, and prognosis. The Scientific World Journal 1-22.

6. Hoang J, Malone J, Callen J (2005) Inverse lichen planus: An unusual morphologic variant of a classic papulosquamous dermatosis. Journal of the American Academy of Dermatology 52: 64.

7. Olson MA, Rogers RS, Bruce AJ (2016) Oral lichen planus. Clin Dermato 34: 495-504.

8. Greenberg MS, Glick M, Ship JA (2008) Burket's Oral Medicine 11th Ed - Greenberg Hamilton, BC Decker. Pg No: 89-97.

9. Lewis MA, Jordan RC (2012) Oral medicine (2nd ed.). London: Manson Publishing. Pg No: 66-72.

10. Gnepp D (2009) Surgical pathology of the head and neck (3rd ed.). Barnes L (ed.). New York: Informa healthcare. New York, USA.

11. ABCDE Limited (2009) Therapeutic guidelines (Version 3. ed.). North Melbourne, Vic.: Therapeutic Guidelines. Pg No: 254-255.

12. Le Cleach L, Chosidow O (2012) Clinical practice. Lichen planus. N Engl J Med 366: 723-32.

13. Asch S, Goldenberg G (2011) Systemic treatment of cutaneous lichen planus: an update. Cutis $87: 129-34$

14. Sharma A, Białynicki-Birula R, Schwartz RA, Janniger CK (2012) Lichen planus: an update and review. Cutis 90: 17-23.

15. Cheng S, Kirtschig G, Cooper S, Thornhill M, Leonardi-Bee J, et al. (2012) Interventions for erosive lichen planus affecting mucosal sites. Cochrane Database Syst Rev 15.

16. Yamada T, Alpers DH, Kalloo AN, Kaplowitz N, Owyang C, et al. (2009 Textbook of Gastroenterology, 5th Edition. Chichester, West Sussex: Blackwell Pub. Pg No: 3304

17. Treister NS, Bruch JM (2010) Clinical oral medicine and pathology. New York: Humana Press. New Jersey, USA.

18. Wagner G, Rose C, Sachse MM (2013) Clinical variants of lichen planus. J Dtsch Dermatol Ges. 11: 309-319.

19. Gorouhi F, Firooz A, Khatami A, Ladoyanni E, Bouzari N, et al. (2009) Interventions for cutaneous lichen planus. Cochrane Database Syst Rev 4.

20. Bolognia JL, Jorizzo JL, Rapini RP (2008) Dermatology, 2nd ed. St. Louis: Mosby/Elsevier.

21. James WD, Berger T, Elston D (2011) Andrews' Diseases of the Skin 11th Edition. London: Saunders/Elsevier. Pg No: 219-224. Freedberg IM, Eisen AZ, Wolff K, Austen KF, Goldsmith LA, et al. (2003) Fitzpatrick's dermatology in general medicine. 6th edition. New York, NY: McGraw-Hill. 51: 470-471.
22. Gordon KA, Vega JM, Tosti A (2011) Trachyonychia: a comprehensive review. Indian J Dermatol Venereol Leprol 77: 640-645.

23. CARF (2016) Cicatricial Alopecia Research Foundation.

24. Freedberg IM, Eisen AZ, Wolff K, Austen KF, Goldsmith LA, et al. (2004) Fitzpatrick's dermatology in general medicine (6th edn). JAAD 51: 325326.

25. James WD, Elston DM, Berger TG, Andrews GC (2011) Andrews' Diseases of the skin: clinical dermatology $\left(11^{\text {th }}\right.$ edn $)$. Saunders Elsevier, London, UK

26. Ebrahimi M, Lundqvist L, Wahlin YB, Nylander E (2012) Mucosal lichen planus, a systemic disease requiring multidisciplinary care: a cross-sectional clinical review from a multidisciplinary perspective. J Low Genit Tract Dis 16: $377-380$

27. Chandan VS, Murray JA, Abraham SC (2008) Esophageal lichen planus. Archives of Pathology \& Laboratory Medicine. 132: 1026-1029.

28. Panagiotopoulou N, Wong CSM, Winter-Roach B (2010) Vulvovaginal-gingival syndrome. Journal of Obstetrics and Gynaecology 30: 226230

29. Schlosser BJ (2010) Lichen planus and lichenoid reactions of the oral mucosa Dermatol Ther 23: 251-267.

30. Nico MM, Fernandes JD, Lourenço SV (2011) Oral lichen planus. An Bras Dermatol 86: 633-641.

31. Alam F, Hamburger J (2001) Oral mucosal lichen planus in children. Int J Paediatr Dent 11:209-214.

32. Farhi D, Dupin N (2010) Pathophysiology, etiologic factors, and clinical management of oral lichen planus, part I: facts and controversies. Clin Dermatol 28: 100-108.

33. Thongprasom K, Carrozzo M, Furness S, Lodi G (2011) Interventions for treating oral lichen planus. Cochrane Database Syst Rev 7: CD001168.

34. Scully C (2013) Oral and maxillofacial medicine: the basis of diagnosis and treatment (3rd edn). Edinburgh: Churchill Livingstone, Pg no: 448.

35. Madalli V, Basavaraddi SM (2013) Lichen Planus -A Review. IOSR Journal of Dental and Medical Sciences 12: 61-69.

36. “UpToDate”. www.uptodate.com. 2019.

37. Lehman JS, Tollefson MM, Gibson LE (2009) Lichen planus. Int J Dermatol 48: 682-694.

38. McCartan BE (1995) Psychological factors associated with oral lichen planus. J Oral Pathol Med 24: 273-275.

39. Eisen D (2002) The clinical features, malignant potential, and systemic associations of oral lichen planus: a study of 723 patients. J Am Acad Dermatol 46: 207-214.

40. Schlosser BJ (2010) Lichen planus and lichenoid reactions of the oral mucosa. Dermatol Ther 23: 251-267.

41. Roopashree MR, Gondhalekar RV, Shashikanth MC, George J, Thippeswamy SH, et al. (2010) Pathogenesis of oral lichen planus--a review. J Oral Pathol Med 39: 729-734. 


\section{Hit \\ HERALD}

Journal of Anesthesia \& Clinical Care

Journal of Addiction \& Addictive Disorders

Advances in Microbiology Research

Advances in Industrial Biotechnology

Journal of Agronomy \& Agricultural Science

Journal of AIDS Clinical Research \& STDs

Journal of Alcoholism, Drug Abuse \& Substance Dependence

Journal of Allergy Disorders \& Therapy

Journal of Alternative, Complementary \& Integrative Medicine

Journal of Alzheimer's \& Neurodegenerative Diseases

Journal of Angiology \& Vascular Surgery

Journal of Animal Research \& Veterinary Science

Archives of Zoological Studies

Archives of Urology

Journal of Atmospheric \& Earth-Sciences

Journal of Aquaculture \& Fisheries

Journal of Biotech Research \& Biochemistry

Journal of Brain \& Neuroscience Research

Journal of Cancer Biology \& Treatment

Journal of Cardiology: Study \& Research

Journal of Cell Biology \& Cell Metabolism

Journal of Clinical Dermatology \& Therapy

Journal of Clinical Immunology \& Immunotherapy

Journal of Clinical Studies \& Medical Case Reports

Journal of Community Medicine \& Public Health Care

Current Trends: Medical \& Biological Engineering

Journal of Cytology \& Tissue Biology

Journal of Dentistry: Oral Health \& Cosmesis

Journal of Diabetes \& Metabolic Disorders

Journal of Dairy Research \& Technology

Journal of Emergency Medicine Trauma \& Surgical Care

Journal of Environmental Science: Current Research

Journal of Food Science \& Nutrition

Journal of Forensic, Legal \& Investigative Sciences

Journal of Gastroenterology \& Hepatology Research

Journal of Gerontology \& Geriatric Medicine

Journal of Genetics \& Genomic Sciences

Journal of Hematology, Blood Transfusion \& Disorders

Journal of Human Endocrinology

Journal of Hospice \& Palliative Medical Care

Journal of Internal Medicine \& Primary Healthcare

Journal of Infectious \& Non Infectious Diseases

Journal of Light \& Laser: Current Trends

Journal of Modern Chemical Sciences

Journal of Medicine: Study \& Research

Journal of Nanotechnology: Nanomedicine \& Nanobiotechnology

Journal of Neonatology \& Clinical Pediatrics

Journal of Nephrology \& Renal Therapy

Journal of Non Invasive Vascular Investigation

Journal of Nuclear Medicine, Radiology \& Radiation Therapy

Journal of Obesity \& Weight Loss

Journal of Orthopedic Research \& Physiotherapy

Journal of Otolaryngology, Head \& Neck Surgery

Journal of Protein Research \& Bioinformatics

Journal of Pathology Clinical \& Medical Research

Journal of Pharmacology, Pharmaceutics \& Pharmacovigilance

Journal of Physical Medicine, Rehabilitation \& Disabilities

Journal of Plant Science: Current Research

Journal of Psychiatry, Depression \& Anxiety

Journal of Pulmonary Medicine \& Respiratory Research

Journal of Practical \& Professional Nursing

Journal of Reproductive Medicine, Gynaecology \& Obstetrics

Journal of Stem Cells Research, Development \& Therapy

Journal of Surgery: Current Trends \& Innovations

Journal of Toxicology: Current Research

Journal of Translational Science and Research

Trends in Anatomy \& Physiology

Journal of Vaccines Research \& Vaccination

Journal of Virology \& Antivirals

Archives of Surgery and Surgical Education

Sports Medicine and Injury Care Journal

International Journal of Case Reports and Therapeutic Studies

Submit Your Manuscript: http://www.heraldopenaccess.us/Online-Submission.php 